ISSN 1424-8220

(C) 2007 by MDPI

www.mdpi.org/sensors

Full Research Paper

\title{
Hazards of Secondary Bromadiolone Intoxications Evaluated using High-performance Liquid Chromatography with Electrochemical Detection
}

\author{
Sona Krizkova ${ }^{1}$, Miroslava Beklova ${ }^{2}$, Jiri Pikula ${ }^{2, *}$, Vojtech Adam ${ }^{1}$, Ales Horna ${ }^{3}$ \\ and René Kizek ${ }^{1}$ \\ ${ }^{1}$ Department of Chemistry and Biochemistry, Faculty of Agronomy, Mendel University of Agriculture \\ and Forestry Brno, Zemedelska 1, CZ-613 00 Brno, Czech Republic \\ ${ }^{2}$ Department of Veterinary Ecology and Environmental Protection, Veterinary and Pharmaceutical \\ University Brno, Palackeho 1/3, CZ-612 42 Brno, Czech Republic \\ ${ }^{3}$ Department of Food Engineering, Faculty of Technology, Tomas Bata University, T.G. Masaryka \\ 275, CZ-762 72 Zlin, Czech Republic \\ * Author to whom correspondence should be addressed; E-mail:pikulaj@vfu.cz
}

Received: 28 June 2007 / Accepted: 18 July 2007 / Published: 20 July 2007

\begin{abstract}
This study reported on the possibility of intoxications of non-target wild animals associated with use of bromadiolone as the active component of rodenticides with anticoagulation effects. A laboratory test was done with earthworms were exposed to bromadiolone-containing granules under the conditions specified in the modified OECD 207 guideline. No mortality of earthworms was observed during the fourteen days long exposure. When the earthworms from the above test became a part of the diet of common voles in the following experiment, no mortality of consumers was observed too. However, electrochemical analysis revealed higher levels of bromadiolone in tissues from earthworms as well as common voles compared to control animals. There were determined comparable levels of bromadiolone in the liver tissue of common voles after primary $(2.34 \pm 0.10 \mu \mathrm{g} / \mathrm{g})$ and secondary $(2.20 \pm 0.53 \mu \mathrm{g} / \mathrm{g})$ intoxication. Therefore, the risk of secondary intoxication of small mammalian species feeding on bromadiolone-containing
\end{abstract}


earthworms is the same as of primary intoxication through baited granules. Bromadiolone bio-accumulation in the food chain was monitored using the newly developed analytical procedure based on the use of a liquid chromatography coupled with electrochemical detector (HPLC-ED). The HPLC-ED method allowed to determine the levels of bromadiolone in biological samples and is therefore suitable for examining the environmental hazards of this substance.

Keywords: anticoagulant rodenticide; electrochemistry, cyclic voltammetry; animal tissues; non-target organisms; Eisenia fetida; Microtus arvalis; Lepus europaeus

\section{Introduction}

Industrial pollutants come from various anthropogenic sources into the environment [1,2]. Agricultural pesticides including rodenticides belong to such group of pollutants [3-6]. Rodenticides are used to control pest rodents that may be harbouring zoonotic infectious agents [7-11]. However, rodenticides may have also direct or indirect effects on non-target organisms [12,13]. Detrimental effects as well as mortality in both domestic [14] and wild non-target animals [4,15] have been shown after use of anticoagulant rodenticides. One of the so-called second-generation anticoagulant rodenticide, bromadiolone, can be found in livers of predators of small rodents such as the fox, marten, and birds of prey at sublethal concentrations [16-18]. Bromadiolone acts as the antagonist of vitamin $\mathrm{K} 1$ and inhibits thus blood clotting (Fig. 1). It may be characterized as having a very low LD50 value and high stability [19]. Therefore bromadiolone may persist in the environment (particular in the soil), bio-accumulate in an organism and cause acute or chronic intoxications [20]. In addition the interaction of bromadiolone and blood plasma proteins is not clear yet. Recently, a study reporting on the interaction of bromadiolone and albumin was published [21].

Several products containing bromadiolone have been approved for use as baited granules in the Czech Republic. The granules disintegrate quickly in the fields of application, thus there is a risk of both primary and secondary intoxications of non-target organisms, because the carrying substances of granules may attract earthworms. The insectivorous and other small mammalian species may possibly become intoxicated by this way (Fig. 2).

Great attention has been paid to the surveillance of residues of pesticides both in the environment and foods [22-27]. Several analytical approaches such as gas chromatography mass spectroscopy, thin layer chromatography or immunochemistry $[28,29]$ may be used to determine bromadiolone. However, high performance liquid chromatography (HPLC) coupled with various detectors (fluorescence or mass detectors) is the most commonly used instrument to detect bromadiolone [30-34]. These instruments, however, suffer from various reason, most of all, high cost. Electrochemical sensors and biosensors have superior properties over the other existing measurement systems because they can provide quick, simple and low-cost on-field determination of many biologically active species and a number of dangerous pollutants [35-57]. 


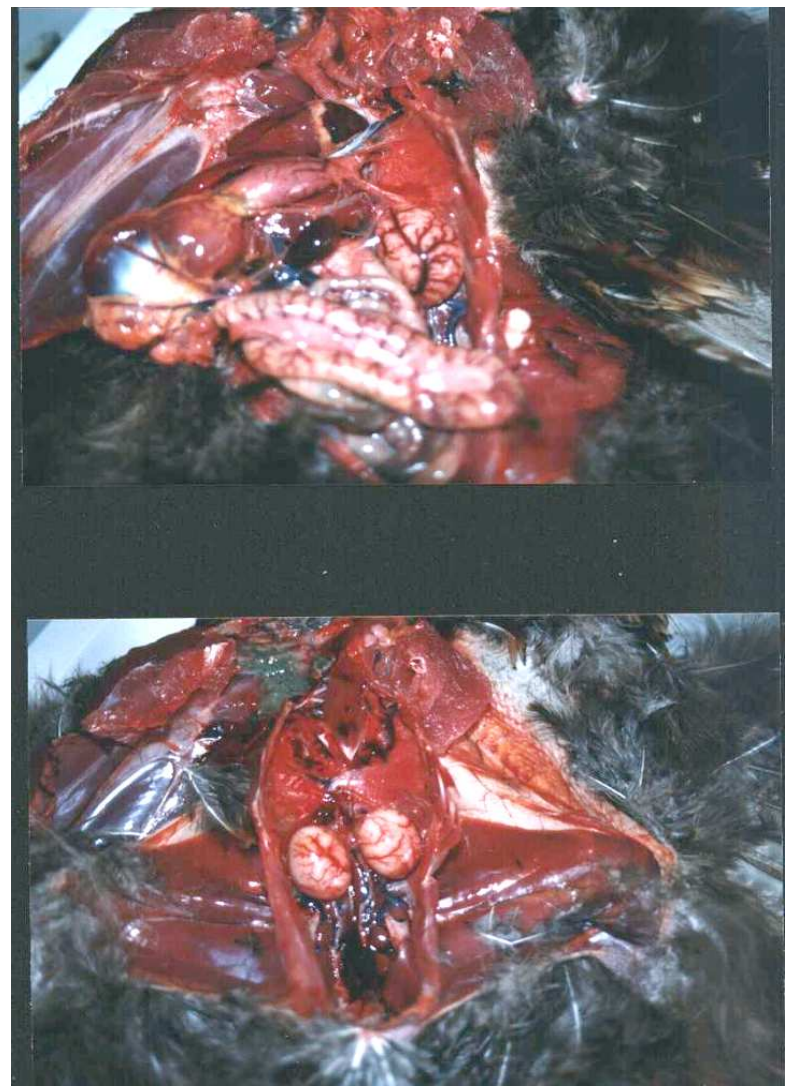

Figure 1. Autopsy of pheasants killed at the end of the experiment revealed no marked pathological changes except for occasional haemorrhages within the breast muscles. The figure shows a typical finding in animals poisoned with rodenticides, so it indicates that the pathological changes were found in opposite to the relatively good health state of pheasants [58].
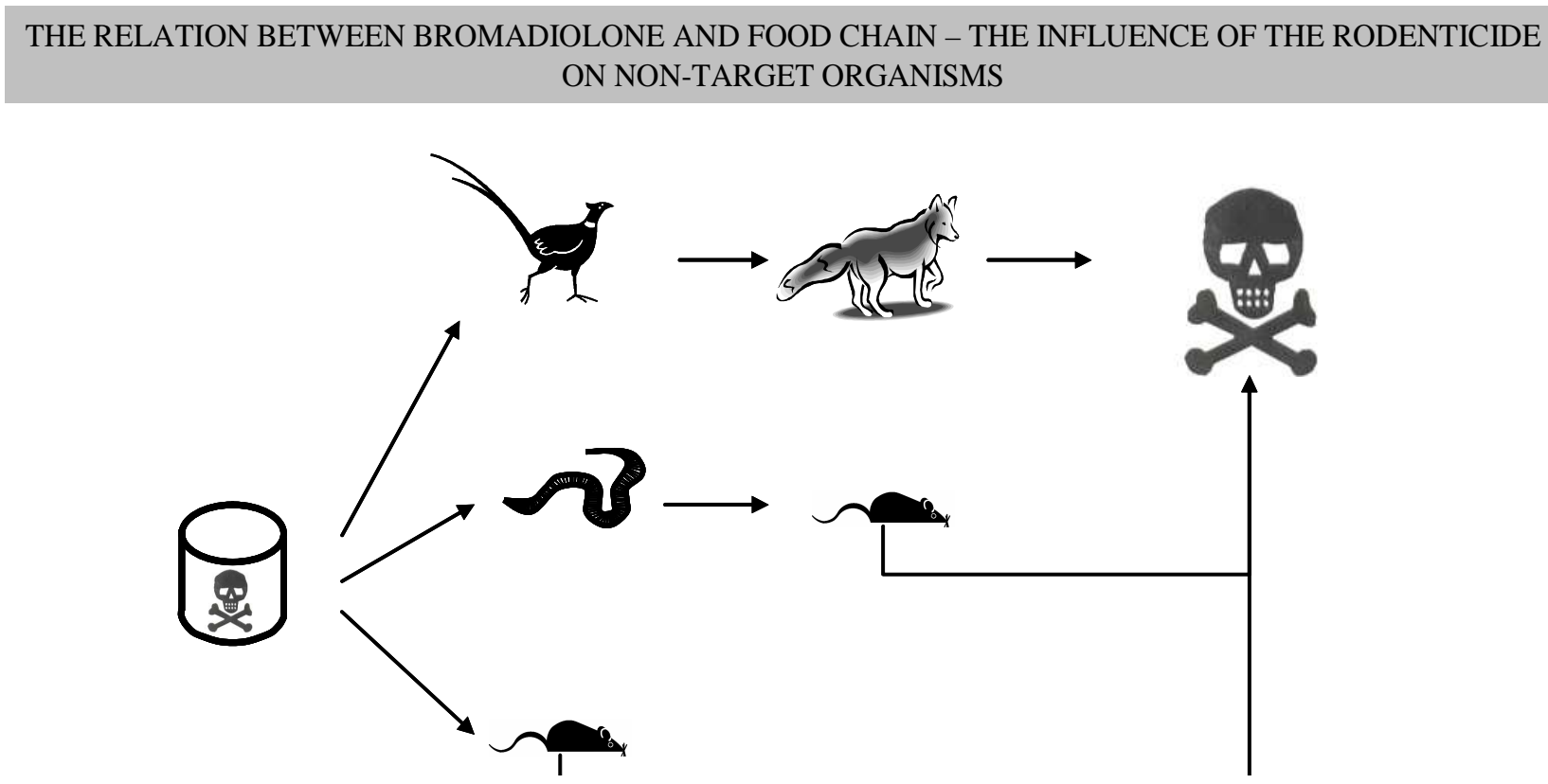

Figure 2. Scheme of the model experiment simulating the bromadiolone distribution within the food chain. 
Considering the above facts, the aim of this work was to propose a new method of bromadiolone detection. We optimized high performance liquid chromatography with electrochemical detection (HPLC-ED) for this purpose and employed this approach to determine the concentration of the target molecule in tissues of animals from two trophic levels.

\section{Experimental Section}

\subsection{Chemicals}

Acetic acid, sodium acetate, acetonitrile (HPLC grade) and bromadiolone (Pestanal - analytical standard) were purchased from Sigma Aldrich (Steinheim, Germany). Methanol was purchased from Fluka (Steinheim, Germany). Water for the preparation of buffers underwent demineralization by reverse osmosis using the instruments Aqua Osmotic 02 (Aqua Osmotic, Tisnov, Czech Republic). Then, it was purified using Millipore RG (Millipore Corp., USA, $18 \mathrm{M} \Omega$ ). Working solutions of the bromadiolone standard were prepared daily by diluting the stock solution of $1 \mathrm{mg} / \mathrm{ml}$ concentration with methanol.

\subsection{Rodenticide-containing product}

The experiment was carried out with a commercially available rodenticide (with $0.005 \%$ of bromadiolone; thereinafter referred as PRODUCT), which is used commonly for the control of common voles in gardens, orchards, vineyards, and non-agricultural land. The PRODUCT is not appropriate for large-scale use but for the application in the voles' burrows. The recommended dose is 5-10 granules per open burrow.

\subsection{Biotests}

\subsubsection{Toxicity for earthworms - test in the artificial soil substrate}

The test was carried out according to the modified OECD 207 guideline [59]. Glass bottles (1,000 $\mathrm{ml}$ ) were filled with $500 \mathrm{~g}$ of the artificial soil test substrate consisting of peat (10\%), kaolin clay (20 $\%$ ), and silica sand (70 \%). The substrate was mixed with 10 granules of the PRODUCT. Demineralised water was added at a level corresponding to $35 \%$ of dry weight of the substrate. Four bottles with the PRODUCT and four control bottles were used in the experiment. Ten laboratory reared individuals of Eisenia fetida were weighed prior to the experiment and placed on the surface of the substrate in each bottle. Only adult individuals with the clitellum were used; the minimum average weight was $400 \mathrm{mg}$. The test was carried out under conditions as follows: temperature of $20 \pm 2{ }^{\circ} \mathrm{C}$ and continual lightning (450-600 lx). The evaluation of the test was performed after 14 days. One half of control earthworms and one half of the earthworms exposed to the PRODUCT were frozen immediately after collecting. The remaining earthworms were used in the following experiment with common voles. 


\subsubsection{Primary and secondary intoxication of common voles}

Nine common voles (Microtus arvalis) from the laboratory rearing were used to experimentally study the possibility of primary and secondary intoxication by bromadiolone. Voles were kept individually in 91 glass aquaria with wood shavings as bedding. Three groups of voles were employed in the experiment lasted 5 days. The first group consisted of control animals were fed with common commercially available granules for laboratory mice. The second group of voles was fed with the PRODUCT granules of which they received $0.086 \mathrm{~g}$ daily. The third group was fed with earthworms, which were previously exposed to PRODUCT granules for 14 days. Drinking water was available ad libitum. To ensure adaptation of voles to earthworms as a feed, the voles used in the experiment were fed with earthworms from the laboratory rearing for a period of 7 days prior to the experiment. At the start of the experiment the average weight of voles from the first, second and third group was $16.6 \mathrm{~g}$, $15.5 \mathrm{~g}$ and $15.6 \mathrm{~g}$, respectively. At the end of the 5-days long experiment, the weight of animals from the fore mentioned groups was 17.3, 15.9 and $15.2 \mathrm{~g}$, respectively. Voles were weighed, euthanized and then subjected to autopsy. No gross pathological lesions were found. The liver was collected from each animal. The average weight of the liver of animals from the fore mentioned groups was $0.95,0.93$ and $0.94 \mathrm{~g}$, respectively.

\subsubsection{Hares}

Three hare cadavers from hunting grounds on agricultural premises in districts to the east of the city of Brno (South Moravia, Czech Republic), where bromadiolone-containing granular baits was used, were collected in November 2005 and used in our experiments.

\subsection{Preparation of biological samples}

The samples of $0.5 \mathrm{~g}$ tissue (earthworm, liver from the treated voles or liver and stomach content of hares) were homogenized with $0.5 \mathrm{ml}$ of methanol using a homogenizer (Ultraturax) for $15 \mathrm{~min}$. The homogenates was sonicated at $150 \mathrm{~W}$ at $4{ }^{\circ} \mathrm{C}$ for $15 \mathrm{~min}$. using $\mathrm{K} 5$ Sonicator (Slovakia) and subsequently vortexed for $15 \mathrm{~min}$. using Vortex-2 Genie (Scientific Industries, New York, USA). The mixture was centrifuged for 20 minutes at $14,000 \mathrm{~g}$ at $4{ }^{\circ} \mathrm{C}$ using Universal $32 \mathrm{R}$ centrifuge (HettichZentrifugen $\mathrm{GmbH}$, Tuttlingen, Germany). Subsequently, the supernatant liquor was collected and stored at $-20{ }^{\circ} \mathrm{C}$ until the next analysis. Prior to the analysis, the samples were diluted $2 \times$ with methanol.

\subsection{Electrochemical measurements in the stationary system}

Electrochemical cyclic voltammetric measurement was carried out using the AUTOLAB Analyser (EcoChemie, The Netherlands) connected to VA-Stand 663 (Metrohm, Switzerland). The threeelectrode system was used; it consisted of the carbon paste electrode (paste composition: 70\% carbon powder and 30\% mineral oil, w/w; the teflon body in which the diameter of the active electrode surface was $2.5 \mathrm{~mm}$; the surface of the electrode was polished prior to each measurement using a fine filtration paper according to [60-62]); reference electrode $\left(\mathrm{Ag} / \mathrm{AgCl} / 3 \mathrm{~mol}^{-1} \mathrm{KCl}\right)$, and the auxiliary electrode from glassy carbon. GPES software (EcoChemie, The Netherlands) was employed to process raw data 
using Level 4 Savitzky and Golay filter. Experiments were carried out at room temperature. The measurement was performed in the potential range from 0.6 to $1 \mathrm{~V}$ using the following parameters: the potential step of $2.4 \mathrm{mV}$, the scan rate of $0.3 \mathrm{~V} . \mathrm{s}^{-1}$. Acetate buffer $(0.2 \mathrm{M}, \mathrm{pH} 4.0)$ was used as a supporting electrolyte.

\subsection{Electrochemical measurements in the flow system}

The flow system consisted of the chromatographic pump (Model 583 ESA Inc., Chelmsford, MA, USA), Guard cell (Model 5020 ESA, USA), reaction loop (1m) for Flow Injection Analysis (FIA), and the chromatographic column Polaris (C18-A, $150 \times 4.6 \mathrm{~mm}$, with particle size of $3 \mu \mathrm{m}$; Varian, Inc.) and the electrochemical detector. The detector consisted of parts as follows: flow amperometric analytical cell (Model 5040, ESA, USA) containing the reference (hydrogen-palladium), auxiliary carbon and the working electrode made of glassy carbon, the Coulochem III control module. The sample $(5 \mu \mathrm{l})$ was injected manually using a $5 \mu$ injection loop (Supelco, Bellefonte, PA, USA). The data from the detector were processed using the CSW 32 software. The isocratic mobile phase consisted of $0.2 \mathrm{M}$ acetate buffer $(\mathrm{pH} 4.0 /$ acetonitrile, 40:60, v/v). The detection potential was optimized; see in "Results" section.

\section{Results}

\subsection{Detection of bromadiolone using cyclic voltammetry}

To employ HPLC with electrochemical detection for measurement of bromadiolone we aimed on study of the basic electrochemical behaviour of the target molecule using cyclic voltammetry at the carbon paste electrode. The voltammograms with a distinct oxidation signal at potential of $836 \mathrm{mV}$ due to bromadiolone are shown in Fig. 3A. Dependence of the peak height on the scan rate was logarithmic $(y=44.413 \ln (x)-78.08)$. In addition, the potential of the peak shifted gradually to positive potentials (Fig. 3B). The dependence of the peak height on the concentration of bromadiolone was also determined. The signal enhanced sharply with the concentration in the given concentration range up to a concentration of $1 \mu \mathrm{g} / \mathrm{ml}$, then more gradually (Fig. 3C). In spite of the fact that the peak height of bromadiolone enhanced with its increasing concentration, but the dependence measured is not strictly linear within the interval. For analytical purposes this dependence can be split into two strictly linear lines at a concentration of bromadiolone ranging from 0.625 to $10 \mu \mathrm{g} / \mathrm{ml}\left(\mathrm{y}=600.53 \mathrm{x}+67.114, \mathrm{R}^{2}=\right.$ 0.9912); and at a concentration of bromadiolone ranging from 20 to $300 \mathrm{ng} / \mathrm{ml}(\mathrm{y}=62.576 \mathrm{x}+259.78$, $\mathrm{R}^{2}=0.9927$, inset in Fig. 3C). The limit of detection for bromadiolone measured on the carbon paste electrode by cyclic voltammetry was evaluated as $5 \mathrm{ng} / \mathrm{ml}$. It can be concluded that $\mathrm{CV}$ is a method suitable for fundamental studying of electrochemical behaviour of a target molecule; however, it can not be used for analysis of real sample due to relative low selectivity. Therefore the experimental results obtained were used in an optimization procedure for the detection of bromadiolone using flow analysis. 


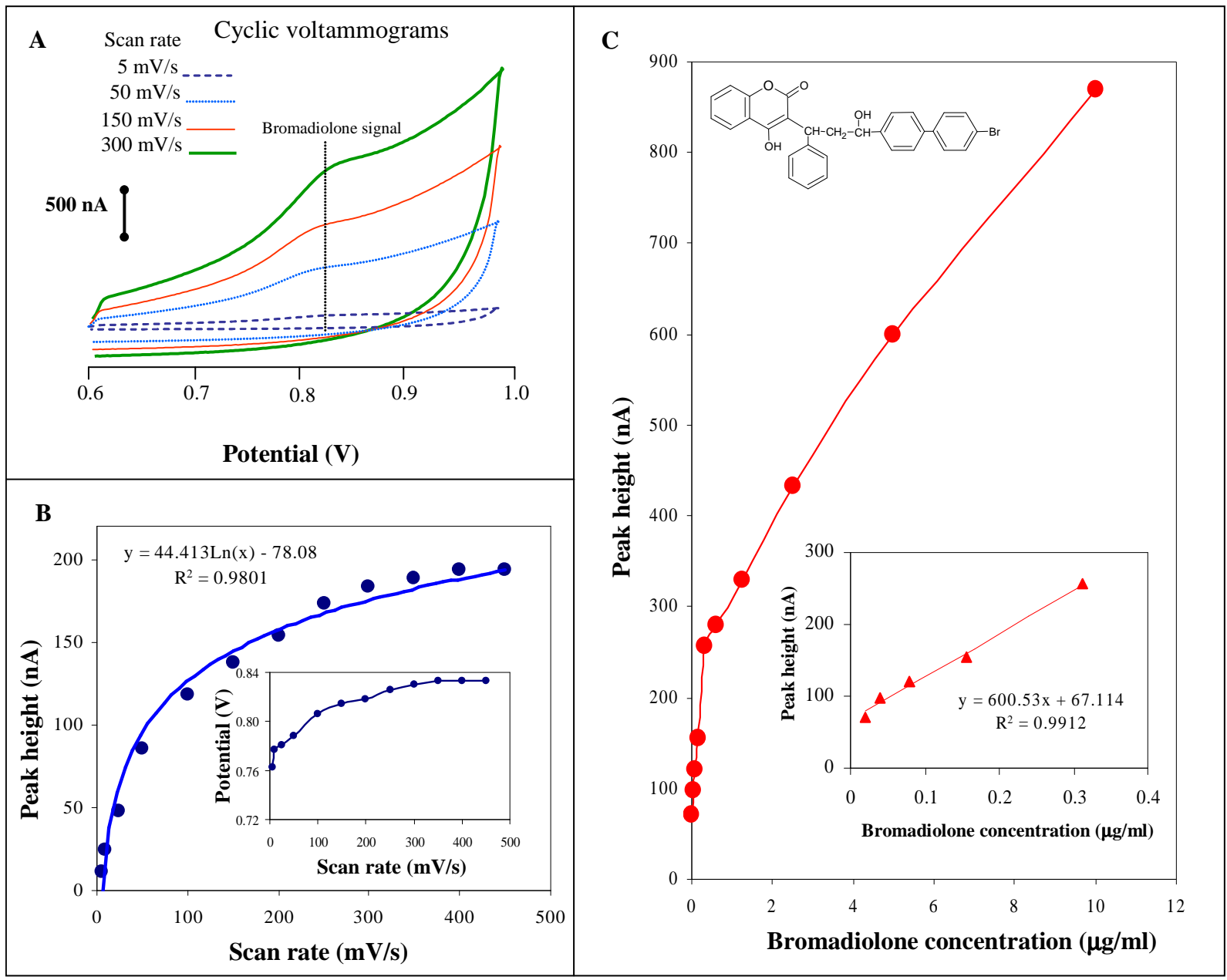

Figure 3. The electrochemical analysis of bromadiolone using cyclic voltammetry. (A) Cyclic voltammograms of bromadiolone $(1 \mu \mathrm{g} / \mathrm{ml})$ at scan rate of 5, 50,150, and $300 \mathrm{mV} / \mathrm{s}$. (B) Dependence of the height and position of potential of the bromadiolone signal on the scan rate. (C) Variation in the

height of the bromadiolone signal on the concentration at a scan rate of $300 \mathrm{mV} / \mathrm{s}$. Parameters of measurement: $0.2 \mathrm{M}$ acetate buffer ( $\mathrm{pH} 4.0$ ), in the potential range from 0.6 to $1 \mathrm{~V}$, potential step: 2.4 $\mathrm{mV}$, experiments were carried out at room temperature.

\subsection{Detection of bromadiolone using flow injection analysis with glassy carbon electrode}

To make the analysis of bromadiolone-containing samples rapid and suitable for routine, a new approach of the detection of bromadiolone using Flow Injection Analysis (FIA) was proposed. The electrochemical response of bromadiolone was studied at a constant flow rate of the mobile phase $(0.5$ $\mathrm{ml} / \mathrm{min}$ ) and a varying working electrode potential. The detection potential of $840 \mathrm{mV}$ was selected based on the hydrodynamic voltammogram (not shown). To obtain the maximum resolution of the bromadiolone peak and the maximum intensity of the signal, the effect of an organic component of the mobile phase (acetonitrile) was studied (Fig. 4A). The increased portion of the organic phase was found beneficial for the detection of bromadiolone. This fact is likely to be associated with the physicochemical properties of bromadiolone as an non-polar compound (more soluble in organic solvents) although our previous studies indicated a significant decrease in the electrochemical signal in the presence of the increased portion of the organic component in the mobile phase [58,63-66]. The flow rate of the mobile phase also affects the electrochemical signal. Variations in the bromadiolone 
signal with the flow rate ranging from $0.1 \mathrm{ml} / \mathrm{min}$ to $2.0 \mathrm{ml} / \mathrm{min}$ were determined. The bromadiolone signal increased at a flow rate up to $0.8 \mathrm{ml} / \mathrm{min}$. Then it did not change (not shown).

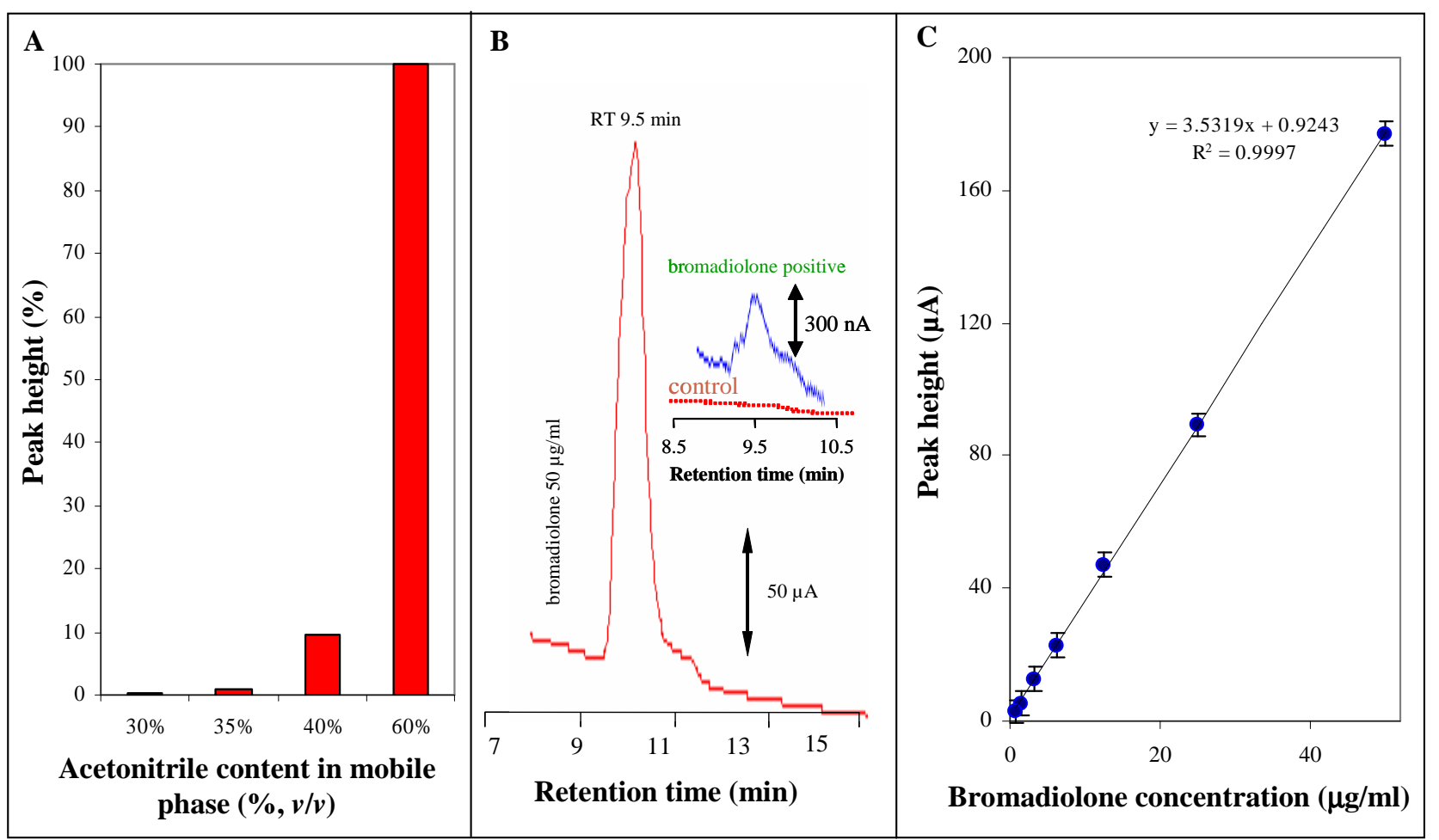

Figure 4. The analysis of bromadiolone using high performance liquid chromatography with electrochemical detection. (A) The effect of the organic component in the mobile phase (acetonitrile) on the bromadiolone peak height. (B) Chromatogram of bromadiolone at a concentration of $50 \mu \mathrm{g} / \mathrm{ml}$, retention time of the peak of $9.5 \mathrm{~min}$. (C) Dependence of the height of the signal on the bromadiolone concentration. Experimental conditions were as follows: chromatographic column Polaris C18-A, 150 $\times 4.6 \mathrm{~mm}$, diameter: $3 \mu \mathrm{m}$ (Varian, Inc.). The sample was injected manually. Isocratic mobile phase consisted of $0.2 \mathrm{M}$ acetate buffer $(\mathrm{pH} 4.0) /$ acetonitrile $(40: 60, v / v)$ and the detection potential of 840 $\mathrm{mV}$ were used. The flow rate of the mobile phase was $0.8 \mathrm{ml} / \mathrm{min}$.

\subsection{High performance liquid chromatographic analysis of bromadiolone}

Under the experimental conditions optimized using FIA (working electrode potential $840 \mathrm{mV}$, mobile phase $0.2 \mathrm{M}$ acetate buffer $(\mathrm{pH} 4.0)$ /acetonitrile (40:60, v/v), the flow rate of the mobile phase $0.8 \mathrm{ml} / \mathrm{min}$ ) high performance liquid chromatography coupled with electrochemical detector was used to determine the content of bromadiolone in real samples. The signal of bromadiolone was observed with the retention time of $9.5 \mathrm{~min}$ (Fig. 4B). In addition, the calibration dependence for bromadiolone at a concentration range from 0.3 to $50 \mu \mathrm{g} / \mathrm{ml}$ was determined. The strictly linear calibration curve was obtained: $y=3.5 x+0.9 ; R^{2}=0.9997$, with a relative standard deviation of about $4 \%$ (Fig. $4 \mathrm{C}$ ). When we proposed the technique for determination of bromadiolone, the toxic effects of the target molecule on various experimental models were investigated. 


\subsection{Bromadiolone exposure}

\subsubsection{Earthworms}

During the 14-days long experiment, all earthworms exposed to bromadiolone survived. At the beginning of the experiment their average weight was $430 \mathrm{mg}$. However, the weight of control earthworms was $293 \mathrm{mg}$ while earthworms exposed to the PRODUCT granules weighed $344 \mathrm{mg}$ at the end of the experiment,. The decrease in the weight of control earthworms (more than $30 \%$ ) was caused by starvation since the substrate contained no suitable nutrients. Earthworms exposed to the PRODUCT granules lost only $20 \%$ of their original weight. They were assumed to have received granules containing bromadiolone. Using the proposed approach of homogenization and extraction, the samples of earthworms (Eisenia fetida) were prepared and subsequently analyzed by HPLC-ED. The average level of bromadiolone was $1.7 \pm 0.2 \mu \mathrm{g}$ per earthworm, which corresponds to $3.3 \pm 0.9 \mu \mathrm{g}$ per $\mathrm{g}$ of earthworm weight (Fig. 5). No signal due to bromadiolone was determined in samples from control earthworms.

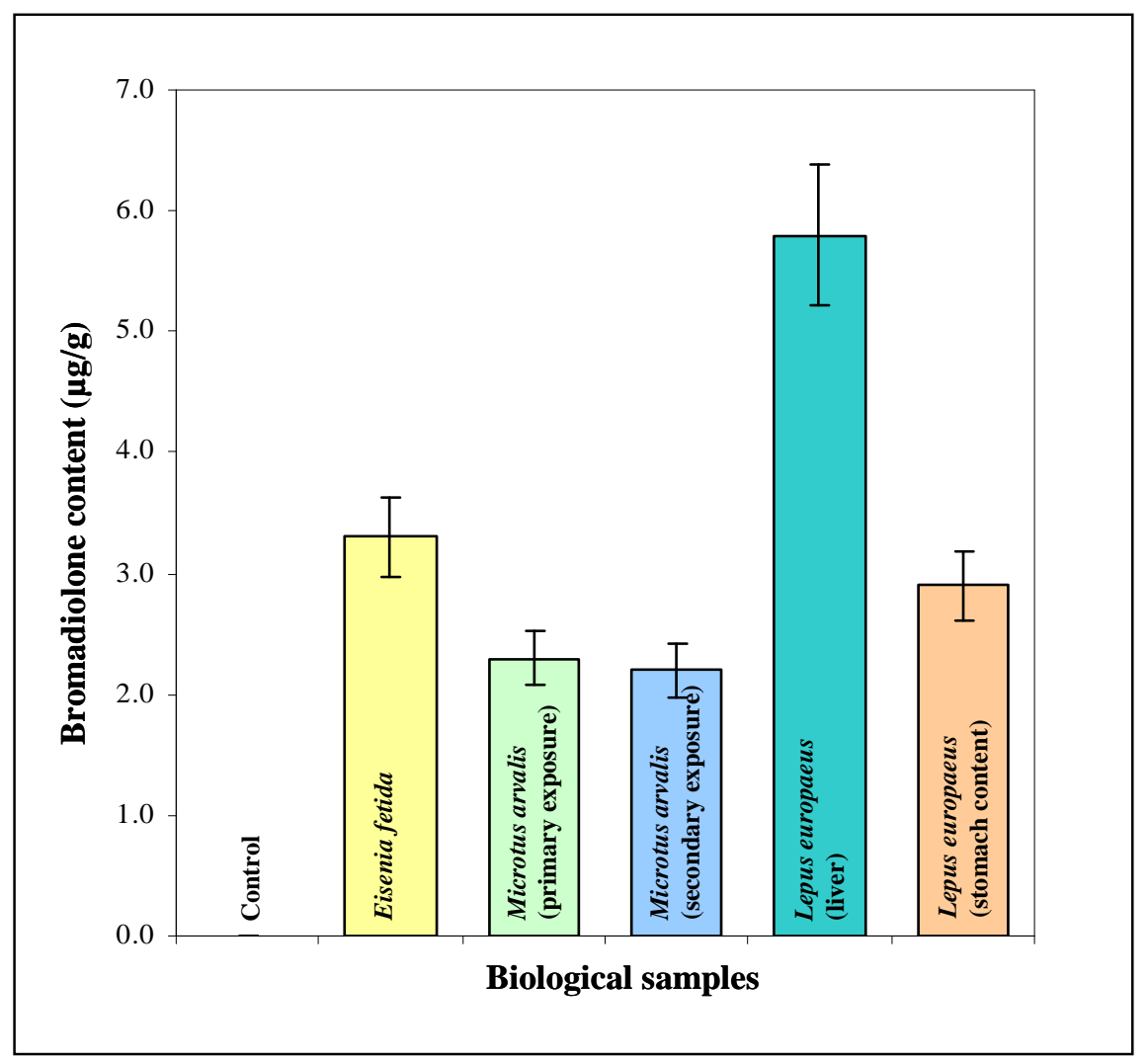

Figure 5. The content of bromadiolone in the tissues from experimental animals. No bromadiolone signal was determined in samples from the controls (voles, earthworms). The levels of bromadiolone in earthworms were recalculated relative to the weight of earthworms. The levels of bromadiolone in voles were recalculated to the weight of the liver. For other details see in Fig. 3 and "Experimental section". 


\subsubsection{Common voles}

The level of bromadiolone in liver tissue from voles fed by the PRODUCT granules determined by HPLC-ED was $2.3 \pm 0.1 \mu \mathrm{g} / \mathrm{g}$. The average level of bromadiolone in liver tissue of voles fed with earthworms exposed to bromadiolone was $2.2 \pm 0.5 \mu \mathrm{g} / \mathrm{g}$ (Fig. 5).

\subsubsection{Hares}

If we clinically examined the hares, two of them had no symptoms of intoxication by a rodenticide. The last hare (adult female) showed clinical symptoms of the intoxication. It was depressed, weak and the visible mucous membranes were pale. Blood was present in the nostrils. Autopsy revealed the hemothorax, hemoperitoneum, heart chambers and aorta without blood clots. The spleen was not enlarged. Samples of the liver and stomach content from all hares were collected for toxicological analysis. Moreover using HPLC-ED the samples of liver tissues and stomach content of three hares suspected from rodenticide poisoning were analyzed. We found out that the content of bromadiolone were $5.8 \pm 0.2 \mu \mathrm{g} / \mathrm{g}$ in the liver and $2.9 \pm 0.3 \mu \mathrm{g} / \mathrm{g}$ in the stomach content of the last hare (Fig. 5). The determined bromadiolone content in analyzed samples was higher than $0.2 \mathrm{mg} / \mathrm{kg}$, which is considered as rodenticide poisoning. The samples of liver tissues and stomach content from other two hares were bromadiolone negative.

\section{Discussion}

Earthworms (Eisenia fetida) are standard species used in terrestrial ecotoxicology [59,67]. It is an epigeal species living in the humus layer of soil rich in organic components. The artificial soil substrate used in this test is rather deficient in the organic components, as documented by the decreasing weight of earthworms at the end of the test. However, the significantly lower decrease in the weight of earthworms kept in the substrate containing the PRODUCT, as compared with the control substrate, confirms the intake of the PRODUCT granules. Thanks to their composition $(99.995 \%$ of a bonding agent and attractants such as lucerne, maize meal, etc.), the PRODUCT granules can be particularly a suitable feed for earthworms in low-productive lands [67]. Due to this the occurrence of bromadiolone can be very expected in tissues of many predators although the respective concentration may not always result in toxic effects [16]. Close attention is being devoted to the occurrence of residues in the environment, with pesticide-derived compounds representing an important group of residues [68]. Moreover earthworms are useful bioindicators of agroecosystem polluting [69]. It has been observed that some copper-containing fungicides decrease soil microbial biomass, lowering the population of earthworms. Contrary to this, it clearly follows from the obtained results that rodenticide-based bromadiolone-containing products have no lethal effects on earthworms and do not reduce the population of these significant soil decomposers.

The common vole (Microtus arvalis) is an herbivorous animal predominantly. Earthworms are therefore not a typical component of its diet. The reason why we used common voles in the experiment was that the common vole is not a protected and, thus endangered species. Moreover we can use voles from our laboratory rearing both for the evaluation of primary and secondary exposures. It is also representative of other small mammalian species that may be endangered by the use of rodenticides for 
plant protection. There are only a few papers reported on the evaluation of secondary poisonings in insectivorous mammals such as shrews fed earthworms exposed to pesticides [70]. The levels of bromadiolone in all samples of the liver collected from common voles exceeded $0.2 \mathrm{mg} / \mathrm{kg}$. Such levels are considered to be beyond the limit of bromadiolone intoxication [16,71]. No pathological changes were observed in experimental voles probably due to the short time of exposure after which they were killed and submitted for laboratory toxicological analysis. In the case of the bromadiolone intake through earthworms (secondary intoxication), the ratio between the values found and the maximum amount of the received bromadiolone is 0.50 while in the case of the PRODUCT granules the analogous ratio is 0.14 . The difference between these two ratios values may indicate that bromadiolone bound in the organic matter is accumulated better in the subsequent consumer as compared with the PRODUCT baited granules. Since the experimental common vole as a herbivorous mammal does not prefer animal-based components in the diet, a greater risk of bromadiolone accumulation mediated by earthworms may be expected in higher trophic levels of the food chain, i.e., many species such as amphibians, reptiles, birds, mammals, and fish for which earthworms are a source of feed.

The routine analysis of pesticide-derived products is based on chromatographic methods with UV detection or less frequently used fluorimetric and mass detection [72-75]. However, electrochemical techniques for the study of these substances have not been used so far. The use of HPLC-ED permitted determining the levels of bromadiolone in biological samples. Thus, this method may be suitable for the evaluation of environmental hazards posed by this substance. At the same time, this method can also be used to study pharmacokinetic properties of bromadiolone. All current HPLC methods proposed for the determination of this substance require expensive devices such mass spectrometer. An analysis using the proposed method is rapid, relatively low cost and also applicable for the determination of trace levels of bromadiolone.

\section{Acknowledgements}

This work was supported by grants of the Ministry of Education of the Czech Republic (project MSMT 6215712402).

\section{References}

1. Kizek, R.; Vacek, J.; Trnkova, L.; Klejdus, B.; Kuban, V. Electrochemical biosensors in agricultural and environmental analysis. Chem. Listy 2003, 97, 1003-1006.

2. Ulrich, R.; Raszyk, J. Variations in environmental contamination by polychlorinated biphenyls (PCB) and chlorinated pesticides (Lindane, DDT) on pig farms in Hodonin district in 1994 to 1999. Vet. Med. 2002, 47, 159-168.

3. Cohen, S.Z.; Creeger, S.M.; Carsel, R.F.; Enfield, C.G. Potential Pesticide Contamination of Groundwater from Agricultural Uses. Acs Symposium Series 1984, 259, 297-325.

4. Cope, R.B. Small animal anticoagulant rodenticide poisoning. Aust. Vet. Pract. 2004, 34, 50-+.

5. Jones, R.L.; Mangels, G. Review of the validation of models used in federal insecticide, fungicide, and rodenticide act environmental exposure assessments. Environ. Toxicol. Chem. 2002, 21, 1535 1544. 
6. Snyder, N.J.; Cartron, J.M.; van Wesenbeeck, I.; Carver, L.S.; Ritter, A.M. Electronic soil moisture measurements in federal insecticide, fungicide, and rodenticide act field dissipation and prospective groundwater studies, American Chemical Society, 2003; 368.

7. Pikula, J.; Treml, F.; Beklova, M.; Holesovska, Z.; Pikulova, J. Geographic information systems in epidemiology - Ecology of common vole and distribution of natural foci of tularaemia. Acta Vet. BRNO 2002, 71, 379-387.

8. Pikula, J.; Treml, F.; Beklova, M.; Holesovska, Z.; Pikulova, J. Ecological conditions of natural foci of tularaemia in the Czech Republic. Eur. J. Epidemiol. 2003, 18, 1091-1095.

9. Pikula, J.; Beklova, M.; Holesovska, Z.; Treml, F. Spatio-temporal aspects of tularemia in Southern Moravia, Czech Republic. Vet. Med. 2004, 49, 15-18.

10. Pikula, J.; Beklova, M.; Holesovska, Z.; Treml, F. Prediction of possible distribution of tularemia in the Czech Republic. Vet. Med. 2004, 49, 61-64.

11. Treml, F.; Pejcoch, M.; Holesovska, Z. Small mammals - natural reservoir of pathogenic leptospires. Vet. Med. 2002, 47, 309-314.

12. Pikula, J.; Beklova, M.; Horakova, J.; Skocovska, B.; Vitula, F. Comparation of toxic effects of rodenticides for birds. Chem. Listy 2005, 99, S77-S79.

13. Beklova, M.; Pikula, J.; Horakova, J.; Skocovska, B.; Vitula, F. Evaluation of environmental hazards of rodenticides. Chem. Listy 2005, 99, S79-S81.

14. Berny, P.J.; de Oliveira, L.A.; Videmann, B.; Rossi, S. Assessment of ruminal degradation, oral bioavailability, and toxic effects of anticoagulant rodenticides in sheep. Am. J. Vet. Res. 2006, 67, 363-371.

15. Stone, W.B.; Okoniewski, J.C.; Stedelin, J.R. Poisoning of wildlife with anticoagulant rodenticides in New York. J. Wildl. Dis. 1999, 35, 187-193.

16. Berny, P.J.; Buronfosse, T.; Buronfosse, F.; Lamarque, F.; Lorgue, G. Field evidence of secondary poisoning of foxes (Vulpes vulpes) and buzzards (Buteo buteo) by bromadiolone, a 4-year survey. Chemosphere 1997, 35, 1817-1829.

17. Fournier-Chambrillon, C.; Berny, P.J.; Coiffier, O.; Barbedienne, P.; Dasse, B.; Delas, G.; Galineau, H.; Mazet, A.; Pouzenc, P.; Rosoux, R.; Fournier, P. Evidence of secondary poisoning of free-ranging riparian mustelids by anticoagulant rodenticides in France: Implications for conservation of European mink (Mustela lutreola). J. Wildl. Dis. 2004, 40, 688-695.

18. Shore, R.F.; Birks, J.D.S.; Afsar, A.; Wienburg, C.L.; Kitchener, A.C. Spatial and temporal analysis of second-generation anticoagulant rodenticide residues in polecats (Mustela putorius) from throughout their range in Britain, 1992-1999. Environ. Pollut. 2003, 122, 183-193.

19. Revathi, K.; Yogananda, M. Effect of bromadiolone on haematology, liver and kidney in Mus musculus. J.Environ. Biol. 2006, 27, 135-140.

20. Murphy, M.J.; Gerken, D.F. The anticoagulant rodenticides, W. B. Saunders Co, 1989; 143 -146.

21. Deepa, S.; Mishra, A.K. Fluorescence spectroscopic study of serum albumin-bromadiolone interaction: fluorimetric determination of bromadiolone. J. Pharm. Biomed. Anal. 2005, 38, 556563.

22. Aprea, C.; Colosio, C.; Mammone, T.; Minoia, C.; Maroni, M. Biological monitoring of pesticide exposure: a review of analytical methods. J. Chromatogr. B 2002, 769, 191-219. 
23. Balinova, A. Strategies for chromatographic analysis of pesticide residues in water. $J$. Chromatogr. A 1996, 754, 125-135.

24. Barcelo, D. A Review of Liquid-Chromatography in Environmental Pesticide Analysis. Chromatographia 1988, 25, 928-936.

25. Cabras, P.; Angioni, A. Pesticide residues in grapes, wine, and their processing products. J. Agric. Food Chem. 2000, 48, 967-973.

26. Pico, Y.; Font, G.; Molto, J.C.; Manes, J. Pesticide residue determination in fruit and vegetables by liquid chromatography-mass spectrometry. J. Chromatogr. A 2000, 882, 153-173.

27. Torres, C.M.; Pico, Y.; Manes, J. Determination of pesticide residues in fruit and vegetables. $J$. Chromatogr. A 1996, 754, 301-331.

28. Berny, P.J.; Buronfosse, T.; Lorgue, G. Anticoagulant Poisoning in Animals - a Simple New High-Performance Thin-Layer Chromatographic (Hptlc) Method for the Simultaneous Determination of 8 Anticoagulant Rodenticides in Liver Samples. J. Anal. Toxicol. 1995, 19, 576580 .

29. Welling, P.G.; Lee, K.P.; Khanna, U.; Wagner, J.G. Comparison of Plasma Concentrations of Warfarin Measured by Both Simple Extraction and Tlc Methods. J. Pharm. Sci. 1970, 59, 1621-\&.

30. Fauconnet, V.; Pouliquen, H.; Pinault, L. Reversed-phase HPLC determination of eight anticoagulant rodenticides in animal liver. J. Anal. Toxicol. 1997, 21, 548-553.

31. Hunter, K. High-Performance Liquid-Chromatographic Strategies for the Determination and Confirmation of Anticoagulant Rodenticide Residues in Animal-Tissues. J. Chromatogr. 1985, 321, 255-272.

32. Marek, L.J.; Koskinen, W.C. Multiresidue analysis of seven anticoagulant rodenticides by LC/ES/MS/MS. Abstr. Pap. Am. Chem. Soc. 2005, 229, U79-U79.

33. Marek, L.J.; Koskinen, W.C. Multiresidue analysis of seven anticoagulant rodenticides by highperformance liquid chromatography/electrospray/mass spectrometry. J. Agric. Food Chem. 2007, 55, 571-576.

34. Kollroser, M.; Schober, C. Determination of coumarin-type anticoagulants in human plasma by HPLC-electrospray ionization tandem mass spectrometry with an ion trap detector. Clin. Chem. 2002, 48, 84-91.

35. Passaro, V.M.N.; Dell'Olio, F.; Casamassima, B.; De Leonardis, F. Guided-wave optical biosensors. Sensors 2007, 7, 508-536.

36. Jaffrezic-Renault, N.; Martelet, C.; Chevolot, Y.; Cloarec, J.P. Biosensors and bio-bar code assays based on biofunctionalized magnetic microbeads. Sensors 2007, 7, 589-614.

37. Pohanka, M.; Pavlis, O.; Skladal, P. Rapid characterization of monoclonal antibodies using the piezoelectric immunosensor. Sensors 2007, 7, 341-353.

38. Wang, C.Y.; Wang, Z.X.; Zhu, A.P.; Hu, X.Y. Voltammetric determination of dopamine in human serum with amphiphilic chitosan modified glassy carbon electrode. Sensors 2006, 6, 1523-1536.

39. Prieto-Simon, B.; Campas, M.; Andreescu, S.; Marty, J.L. Trends in flow-based biosensing systems for pesticide assessment. Sensors 2006, 6, 1161-1186.

40. Chailapakul, O.; Ngamukot, P.; Yoosamran, A.; Siangproh, W.; Wangfuengkanagul, N. Recent electrochemical and optical sensors in flow-based analysis. Sensors 2006, 6, 1383-1410. 
41. Diculescu, V.C.; Paquim, A.M.C.; Brett, A.M.O. Electrochemical DNA sensors for detection of DNA damage. Sensors 2005, 5, 377-393.

42. Labuda, J.; Bubnicova, K.; Kovalova, L.; Vanickova, M.; Mattusch, J.; Wennrich, R. Voltammetric detection of damage to DNA by arsenic compounds at a DNA biosensor. Sensors 2005, 5, 411-423.

43. Trnkova, L.; Jelen, F.; Petrlova, J.; Adam, V.; Potesil, D.; Kizek, R. Elimination voltammetry with linear scan as a new detection method for DNA sensors. Sensors 2005, 5, 448-464.

44. Adam, V.; Zehnalek, J.; Petrlova, J.; Potesil, D.; Sures, B.; Trnkova, L.; Jelen, F.; Vitecek, J.; Kizek, R. Phytochelatin modified electrode surface as a sensitive heavy-metal ion biosensor. Sensors 2005, 5, 70-84.

45. Lei, Y.; Mulchandani, P.; Chen, W.; Mulchandani, A. Biosensor for direct determination of fenitrothion and EPN using recombinant Pseudomonas putida JS444 with surface expressed organophosphorus hydrolase. 1. Modified Clark oxygen electrode. Sensors 2006, 6, 466-472.

46. Schoning, M.J. "Playing around" with field-effect sensors on the basis of EIS structures, LAPS and ISFETs. Sensors 2005, 5, 126-138.

47. Huang, X.J.; Liu, J.H.; Pi, Z.X.; Yu, Z.L. Detecting pesticide residue by using modulating temperature over a single SnO2-based gas sensor. Sensors 2003, 3, 361-370.

48. Schoning, M.J.; Arzdorf, M.; Mulchandani, P.; Chen, W.; Mulchandani, A. Towards a capacitive enzyme sensor for direct determination of organophosphorus pesticides: Fundamental studies and aspects of development. Sensors 2003, 3, 119-127.

49. Babula, P.; Huska, D.; Hanustiak, P.; Baloun, J.; Krizkova, S.; Adam, V.; Hubalek, J.; Havel, L.; Zemlicka, M.; Horna, A.; Beklova, M.; Kizek, R. Flow injection analysis coupled with carbon electrodes as the tool for analysis of naphthoquinones with respect to their content and functions in biological samples. Sensors 2006, 11, 1466-1482.

50. Prasek, J.; Adamek, M.; Hubalek, J.; Adam, V.; Trnkova, L.; Kizek, R. New hydrodynamic electrochemical arrangement for cadmium ions detection using thick-film chemical sensor electrodes. Sensors 2006, 11, 1498-1512

51. Supalkova, V.; Huska, D.; Diopan, V.; Hanustiak, P.; Zitka, O.; Stejskal, K.; Baloun, J.; Pikula, J.; Havel, L.; Zehnalek, J.; Adam, V.; Trnkova, L.; Beklova, M.; Kizek, R. Electroanalysis of plant thiols. Sensors 2007, 7, 932-959.

52. Supalkova, V.; Petrek, J.; Baloun, J.; Adam, V.; Bartusek, K.; Trnkova, L.; Beklova, M.; Diopan, V.; Havel, L.; Kizek, R. Multi-instrumental investigation of affecting of early somatic embryos of Spruce by cadmium(II) and lead(II) ions. Sensors 2007, 7, 743-759.

53. Supalkova, V.; Petrek, J.; Havel, L.; Krizkova, S.; Petrlova, J.; Adam, V.; Potesil, D.; Babula, P.; Beklova, M.; Horna, A.; Kizek, R. Electrochemical sensors for detection of acetylsalicylic acid. Sensors 2006, 11, 1483-1497.

54. Vitecek, J.; Petrlova, J.; Adam, V.; Havel, L.; Kramer, K.J.; Babula, P.; Kizek, R. A fluorimetric sensor for detection of one living cell. Sensors 2007, 7, 222-238.

55. Adam, V.; Krizkova, S.; Zitka, O.; Trnkova, L.; Petrlova, J.; Beklova, M.; Kizek, R. A determination of apo-metallothionein using adsorptive transfer stripping technique in connection with differential pulse voltammetry. Electroanalysis 2007, 19, 339-347. 
56. Adam, V.; Petrlova, J.; Potesil, D.; Zehnalek, J.; Sures, B.; Trnkova, L.; Jelen, F.; Kizek, R. Study of metallothionein modified electrode surface behaviour in the presence of heavy metal ions biosensor. Electroanalysis 2005, 17, 1649-1657.

57. Petrlova, J.; Potesil, D.; Zehnalek, J.; Sures, B.; Adam, V.; Trnkova, L.; Kizek, R. Cisplatin electrochemical biosensor. Electrochim. Acta 2006, 51, 5169-5173.

58. Beklova, M.; Krizkova, S.; Supalkova, V.; Mikelova, R.; Adam, V.; Pikula, J.; Kizek, R. Determination of bromadiolone in pheasants and foxes by differential pulse voltammetry. Int. J. Environ. Anal. Chem. 2007, 87, 459-469.

59. OECD guideline for testing chemicals No. 207. Earthworm, acute toxicity tests, Organisation for Economics Cooperation and Development, 1984;

60. Kizek, R.; Masarik, M.; Kramer, K.J.; Potesil, D.; Bailey, M.; Howard, J.A.; Klejdus, B.; Mikelova, R.; Adam, V.; Trnkova, L.; Jelen, F. An analysis of avidin, biotin and their interaction at attomole levels by voltammetric and chromatographic techniques. Anal. Bioanal. Chem. 2005, 381, 1167-1178.

61. Masarik, M.; Kizek, R.; Kramer, K.J.; Billova, S.; Brazdova, M.; Vacek, J.; Bailey, M.; Jelen, F.; Howard, J.A. Application of avidin-biotin technology and adsorptive transfer stripping squarewave voltammetry for detection of DNA hybridization and avidin in transgenic avidin maize. Anal. Chem. 2003, 75, 2663-2669.

62. Petrlova, J.; Masarik, M.; Potesil, D.; Adam, V.; Trnkova, L.; Kizek, R. Zeptomole detection of streptavidin using carbon paste electrode and square wave voltammetry. Electroanalysis 2007, 19, 1177-1182.

63. Billova, S.; Kizek, R.; Jelen, F.; Novotna, P. Square-wave voltammetric determination of cefoperazone in a bacterial culture, pharmaceutical drug, milk, and urine. Anal. Bioanal. Chem. 2003, 377, 362-369.

64. Klejdus, B.; Vacek, J.; Adam, V.; Zehnalek, J.; Kizek, R.; Trnkova, L.; Kuban, V. Determination of isoflavones in soybean food and human urine using liquid chromatography with electrochemical detection. J. Chromatogr. B 2004, 806, 101-111.

65. Potesil, D.; Mikelova, R.; Adam, V.; Kizek, R.; Prusa, R. Change of the protein p53 electrochemical signal according to its structural form - Quick and sensitive distinguishing of native, denatured, and aggregated form of the "guardian of the genome". Protein J. 2006, 25, 23 32.

66. Potesil, D.; Petrlova, J.; Adam, V.; Vacek, J.; Klejdus, B.; Zehnalek, J.; Trnkova, L.; Havel, L.; Kizek, R. Simultaneous femtomole determination of cysteine, reduced and oxidized glutathione, and phytochelatin in maize (Zea mays L.) kernels using high-performance liquid chromatography with electrochemical detection. J. Chromatogr. A 2005, 1084, 134-144.

67. Kula, H.; Larink, O. Tests on the Earthworms Eisenia fetida and Aporrectodea caliginosa, John Wiley \& Sons, 1998; 281.

68. Atterby, H.; Kerins, G.M.; MacNiccoll, A.D. Whole-carcass residues of the rodenticide difenacoum in anticoagulant-resistant and -susceptible rat strains (Rattus norvegicus). Environ. Toxicol. Chem. 2005, 24, 318-323. 
69. Paoletti, M.G.; Sommaggio, D.; Favretto, M.R.; Petruzzelli, G.; Pezzarossa, B.; Barbafieri, M. Earthworms as useful bioindicators of agroecosystem sustainability in orchards and vineyards with different inputs. Appl. Soil Ecol. 1998, 10, 137-150.

70. Dell'Omo, G.; Turk, A.; Shore, R.E. Secondary poisoning in the common shrew (Sorex araneus) fed earthworms exposed to an organophosphate pesticide. Environ. Toxicol. Chem. 1999, 18, 237 240.

71. Brown, P.; Charlton, A.; Cuthbert, M.; Barnett, L.; Ross, L.; Green, M.; Gillies, L.; Shaw, K.; Fletcher, M. Identification of pesticide poisoning in wildlife. J. Chromatogr. A 1996, 754, 463478.

72. Guan, F.; Ishii, A.; Seno, H.; Watanabe, K.; Kumazawa, T.; Suzuki, O. A method for simultaneous determination of five anticoagulant rodenticides in whole blood by highperformance liquid chromatography. J. Pharm. Biomed. Anal. 1999, 21, 179-185.

73. Guan, F.Y.; Ishii, A.; Seno, H.; Watanabe-Suzuki, K.; Kumazawa, T.; Suzuki, O. Use of an ionpairing reagent for high-performance liquid chromatography-atmospheric pressure chemical ionization mass spectrometry determination of anionic anticoagulant rodenticides in body fluids. $J$. Chromatogr. B 1999, 731, 155-165.

74. Obryan, S.M.; Constable, D.J.C. Quantification of Brodifacoum in Plasma and Liver-Tissue by Hplc. J. Anal. Toxicol. 1991, 15, 144-147.

75. Park, S.W.; Seo, B.S.; Kim, E.H.; Kim, D.H.; Paeng, K.J. Purification and determination procedure of coumarin derivatives. J. Forensic Sci. 1996, 41, 685-688.

(C) 2007 by MDPI (http://www.mdpi.org). Reproduction is permitted for noncommercial purposes. 